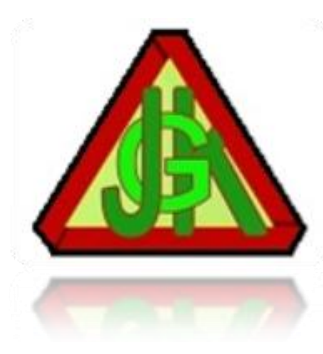

\title{
PENGARUH PENDIDIKAN KESEHATAN DENGAN MEDIA POSTER TERHADAP PERILAKU PENCEGAHAN COVID-19 PADA SEKAA TERUNA TERUNI
}

\author{
I Gusti Ketut Gede Ngurah ${ }^{1}$, I Gusti Ayu Ngurah Viola Utami Dewi ${ }^{2}$, \\ I Ketut Gama ${ }^{3}$ \\ 1,2,3 Politeknik Kesehatan Kemenkes Denpasar, \\ Denpasar, Indonesia \\ e-mail : agungkusuma69@gmail.com ${ }^{1}$, viola_utami@gmail.com² \\ ketutgama22@gmail.com
}

\begin{abstract}
Abstrak
Sangat penting untuk menyusun langkah-langkah pencegahan penularan COVID19 dan memutus rantai transmisi melalui pemberian pendidikan kesehatan dengan media poster terhadap perilaku pencegahan penularan COVID-19 dengan sasaran sekaa teruna teruni. Tujuan penelitian ini adalah untuk mengetahui adanya pengaruh pendidikan kesehatan dengan media poster terhadap perilaku pencegahan COVID-19 pada sekaa teruna teruni di Desa/Kelurahan Gilimanuk tahun 2021. Jenis penelitian yaitu pre-experimental designs dengan rancangan one-group pra-posttest design. Populasi penelitian berjumlah 250 orang. Teknik sampling menggunakan stratified random sampling, didapatkan sampel 77 orang. Dalam penelitian ini perilaku sebelum diberikan pendidikan kesehatan sebagian besar pengetahuannya berada pada kategori cukup (37.7\%), sikap pada kategori baik $(62.3 \%)$, dan tindakan pada kategori baik (35.1\%). Setelah dilakukan pendidikan kesehatan, pengetahuan, sikap dan tindakan berada pada kategori baik. Hasil penelitian diuji dengan uji statistik Wilcoxon didapatkan nilai p-value pada kolom Sig. 2-tailed $=0.000<$ alpha (0.05). Kesimpulan ada pengaruh yang signifikan pendidikan kesehatan dengan media poster terhadap perilaku pencegahan coronavirus disease (COVID-19) pada sekaa teruna-teruni. Saran agar STT dapat menerapkan perilaku pencegahan yang sudah diberikan, dan bagi peneliti selanjutnya agar dapat mengembangkan penelitian serupa dengan media lainnya.
\end{abstract}

Kata kunci : Perilaku, Pencegahan COVID-19, Media poster

\begin{abstract}
It is very important to develop steps to prevent transmission of COVID-19 and break the chain of transmission through the provision of health education so that researchers are interested in examining whether there is an effect of health education with poster media on the behavior of preventing transmission of COVID-19 with the target of sekaa teruni teruni in the village/ Gilimanuk Village The research objective was to determine the effect of health education with poster media on the prevention behavior of COVID-1 in STT in Gilimanuk in 2021. This
\end{abstract}


type of research was pre-experimental designs with one-group pre-posttest design. The study population numbered 250 people. The sampling technique used stratified random sampling, obtained a sample of 77 people. In this study, most of the behaviors before being given health education were in the sufficient category (37.7\%), the attitude was in the good category (62.3\%), and the action was in the good category (35.1\%). After health education was carried out, knowledge, attitudes and actions were in the good category. Hypothesis test used Wilcoxon statistical test, and the p-value was obtained in the Sig column. 2-tailed $=0.000$ <alpha (0.05). The conclusion is that there is a significant effect of health education with media posters on the prevention behavior of coronavirus disease (COVID-19) in STT. Suggestions for STT to implement preventive behaviors that have been given, and for future researchers to be able to develop similar research with other media.

Keywords : Behavior, prevention of COVID-19, media posters

\section{PENDAHULUAN}

Coronavirus Disease 2019 (COVID-19) adalah penyakit yang disebabkan oleh virus corona jenis baru yang disebut SARS-CoV-2. World Health Organization (WHO) pertama kali mengetahui virus baru ini pada 31 Desember 2019 karena adanya laporan sekelompok kasus yang mirip seperti pneumonia di Wuhan, Republik Rakyat China. ${ }^{1}$ Etiologi penyakit ini diketahui pasti yaitu termasuk dalam virus ribonucleid acid (RNA) yaitu virus corona jenis baru, betacorona virus dan satu kelompok dengan virus corona penyebab Severe Acute Respiratory Syndrome (SARS) dan Middle East Respiratory Syndrome (MERS CoV). Diagnosis ditegakkan dengan risiko perjalanan dari Wuhan atau Negara terjangkit dalam kurun waktu 14 hari disertai gejala infeksi saluran nafas atas atau bawah, disertai bukti laboratorium pemeriksaan Real Time Polymerase Chain Reaction (RT-PCR) COVID-19. Menurut Yurianto dkk. (2020), penderita COVID-19 diklasifikasikan menjadi pasien dalam pengawasan (PDP), orang dalam pemantauan (ODP), orang tanpa gejala (OTG) dan pasien terkonfirmasi bila didapatkan hasil RT-PCR COVID-19 positif dengan gejala apapun. ${ }^{2}$

Gejala yang dialami oleh pasien COVID-19 berbeda-beda tiap orang. Gejala yang paling umum yaitu demam, batuk kering dan kelelahan. Sedangkan gejala serius yang dapat dialami oleh pasien COVID-19 antara lain; 
kesulitan bernapas, nyeri dada hingga hilangnya kemampuan berbicara dan bergerak. Rata-rata gejala akan muncul 5-6 hari setelah seseorang pertama kali terinfeksi virus ini tetapi bisa juga 14 hari setelah terinfeksi. ${ }^{1}$ Secara umum, penularan paling efektif virus Corona antarmanusia adalah droplet atau cairan, cairan yang mengandung virus Corona keluar melalui batuk atau bersin, lalu menempel di bagian mulut atau hidung seseorang, kemudian terhirup saat mengambil napas dan masuk ke paru-paru. ${ }^{3}$

Melihat mudahnya penularan COVID-19 antarmanusia, tidak salah jika setiap harinya laporan kasus terkonfirmasi COVID-19 terus meningkat. Data sebaran COVID-19 secara global per 09 Januari 2021 sebanyak 87.273,380 orang terkonfirmasi dan 1.899,440 orang meninggal dunia yang tersebar di 222 negara. Di Indonesia sendiri, pravalensi COVID-19 cukup tinggi. Kasus yang pertama kali terkonfirmasi di Indonesia pada tanggal 02 Maret 2020 dimana jumlahnya hanya dua penderita. Namun, hingga saat ini data sebaran COVID19 di Indonesia terus meningkat, per 09 Januari 2021 jumlah orang yang terkonfirmasi positif COVID-19 mencapai 818.386 orang, sembuh 673.511 orang dan meninggal dunia 23.947 orang. $^{4}$

Dampak dari pandemi COVID-19 tidak hanya pada kesehatan dan nyawa manusia tapi mempengaruhi berbagai aspek kehidupan juga. Pembatasan aktivitas, terhambatnya kegiatan ekspor-impor, hingga pembatasan jumlah penerbangan (domestik-internasional) menyebabkan melemahnya sektor perekonomian dan pariwisata. Bali merupakan salah satu provinsi di Indonesia yang menjadi magnet dunia sehingga banyak tourist mancanegara yang berkunjung ke Bali untuk menikmati keindahan alam, keunikan budaya, dan lainlain. Namun, setelah pandemi COVID-19 meluas menuntut pemerintah untuk mengambil upaya preventif penularan COVID-19 mengingat jumlah pasien terkonfirmasi COVID- 19 di Bali terus meningkat. Berdasarkan data dari Kementerian Kesehatan \& JHU pasien terkonfirmasi positif COVID-19 per 10 Januari 2021 sebanyak 11.846, dinyatakan sembuh 10.766 orang dan meninggal dunia 391 orang yang tersebar di 8 kabupaten dan 1 kota madya. ${ }^{5}$

Salah satu kabupaten terdampak di Provinsi Bali adalah Kabupaten 
Jembrana karena merupakan salah satu pintu masuk orang-orang yang akan ke Bali melalui pelabuhan Gilimanuk. Berdasarkan data dari Pemerintah Kabupaten Jembrana, per 10 Januari 2021 jumlah pasien terkonfirmasi positif COVID-19 sebanyak 1.016 orang, sembuh 877 orang dan meninggal 29 orang. Bencana pandemi ini mempengaruhi aktifitas orang yang menggantungkan mata pencahariannya di pelabuhan termasuk warga sekitar pelabuhan salah satunya di Desa/Kelurahan Gilimanuk. Pemerintah Kabupaten Jembrana mencatat per 10 Januari 2021 kasus positif COVID-19 di Gilimanuk sebanyak 18 orang, sembuh 16 orang dan meninggal dunia 1 orang. Melihat angka tersebut, masyarakat Gilimanuk perlu memiliki kesadaran yang tinggi mengenai ancaman yang dapat mengancam jiwa mengingat daerahnya menjadi jalur utama yang dilalui oleh orang-orang yang akan ke Bali sehingga mereka perlu mengetahui pentingnya perilaku pencegahan penularan COVID-19. ${ }^{6}$

Perilaku adalah suatu kegiatan atau aktivitas organisme atau makhluk hidup yang bersangkutan. Perilaku merupakan respons atau reaksi seseorang terhadap stimulus. ${ }^{13}$ Sejalan dengan batasan perilaku menurut Skiner maka perilaku kesehatan adalah respons seseorang terhadap stimulus atau objek yang berkaitan dengan sehat-sakit, penyakit, dan faktor-faktor yang mempengaruhi sehat-sakit. Pemeliharaan kesehatan ini mencakup mencegah atau melindungi diri dari penyakit dan masalah kesehatan lain, meningkatkan kesehatan, dan mencari penyembuhan apabila sakit atau terkena masalah kesehatan melalui berbagai macam upaya. ${ }^{7}$

Upaya penanganan dan pencegahan penularan COVID-19 sudah diupayakan oleh pemerintah dengan membentuk satuan tugas COVID-19 berdasarkan Keputusan Presiden Republik Indonesia nomor 7 Tahun 2020. Pemerintah Pusat melalui Gugus Tugas Percepatan Penanganan COVID- 19 telah membuat empat strategi demi mengatasi pandemi Virus Corona COVID antara lain: gerakan wajib menggunakan masker saat berada di ruang publik, penelusuran kontak (tracing) dari kasus positif yang dirawat dengan menggunakan rapid test, edukasi dan penyiapan isolasi secara mandiri pada hasil tracing yang menunjukkan hasil positif, dan isolasi Rumah Sakit yang dilakukan 
I Gusti Ketut Gede Ngurah, I Gusti Ayu Ngurah Viola Utami Dewi. Desember 2021. 14 (2): 83-95

apabila isolasi mandiri mandiri tidak cukup karena penderita mengalami gejala klinis yang membutuhkan layanan definitif di Rumah Sakit. ${ }^{4}$ Upaya yang dapat dilakukan untuk mengurangi risiko penularan di masyarakat, individu disarankan untuk rajin mencuci tangan, menutup mulut saat batuk, menghindari keramaian dan kontak dengan individu yang sakit. ${ }^{8}$

Berpedoman pada berbagai upaya dan ketetapan dari pemerinah pusat, pemerintah daerah mengimplementasikannya sesuai kondisi yang ada di daerahnya. Pemerintah Provinsi Bali sendiri telah melakukan upaya penanganan COVID-19 dengan melibatkan desa adat sebagai tim satuan tugas penanganan COVID-19 diawali dengan pertemuan antara pemerintah Provinsi Bali dengan Majelis Desa Adat (MDA) Provinsi Bali menghasilkan surat keputusan nomor 472/1571/PPDA/DPMA dan Nomor 05/SK/MDA-ProvBali/III/2020 tertanggal 28 Maret 2020. Bentuk implementasi dari kebijakan itu dilaksanakan berdasarkan konsep Tri Hita Karana yang terdiri dari parhyangan dengan melakukan ritual agama seperti membatasi kegiatan agama dan pendekatan religius, pawongan dengan melakukan pengawasan keluar masuknya masyarakat dan pembagian masker oleh pecalang (polisi adat), dan palemahan melakukan penyediaan tempat cuci tangan dan penyemprotan disinfektan di lingkungan desa adat. $^{4}$

Salah satu desa adat yang sudah melakukan upaya pencegahan penularan COVID-19 adalah Desa/Kelurahan Gilimanuk. Desa/Kelurahan Gilimanuk terdiri dari 6 lingkungan yang dikelompokkan lagi menjadi 3 banjar. Lingkungan Asri, Lingkungan Asih, Lingkungan Arum termasuk dalam wilayah Banjar Prasta Guna, Lingkungan Samiana, dan Lingkungan Penginuman termasuk dalam wilayah Banjar Niti Dharma, Lingkungan Jineng Agung termasuk dalam wilayah Banjar Werdhi Agung. Berdasarkan hasil wawancara dengan ketua sekaa teruna teruni di masing-masing banjar di Desa/Kelurahan Gilimanuk jumlah sekaa teruna teruni di Desa/Kelurahan Gilimanuk sebanyak 50 di Banjar di Banjar Prasta Guna, 70 di Banjar Werdhi Agung, dan 130 di Banjar Niti Dharma sehingga total seluruh sekaa teruna teruni sebanyak 250. Dikatakan juga masing-masing banjar telah melakukan beberapa upaya untuk pencegahan penularan COVID-19 seperti 
penyuluhan dari desa, penyemprotan desinfektan secara rutin, pengadaan tempat cuci tangan di fasilitas umum, gerakan wajib memakai masker. Namun, ketua sekaa teruna teruni mengatakan masih ada masalah terkait upaya pencegahan penularan COVID-19 ini salah satunya di Banjar Werdhi Agung yaitu masih ada beberapa masyarakat yang perilakunya kurang baik dengan tidak mentaati protokol kesehatan untuk wajib menggunakan masker. ${ }^{6}$ Terdapat 3 domain perilaku antara lain pengetahuan, sikap dan tindakan. Sehingga untuk dapat mengubah perilaku seseorang, perlu mengenai ketiga domain tersebut. Langkah awal yang dapat dilakukan adalah melalui pemberian pendidikan kesehatan. $^{7}$

Pendidikan kesehatan adalah proses untuk memampukan masyarakat dalam memelihara dan meningkatkan kesehatannya. Salah satu media yang dapat digunakan dalam memberikan pendidikan kesehatan adalah poster. 9 Poster merupakan salah satu media pendidikan kesehatan yang menggunakan huruf dengan ukuran besar dan jelas serta berisi gambar. ${ }^{10}$

Berdasarkan hasil penelitian Ulum dengan judul Pengaruh Pemanfaatan Media Poster Terhadap Perilaku Siswa Dalam Menjaga Kebersihan Lingkungan di Kelas II Mi Nashrul Fajar Meteseh Tembalang Semarang didapatkan hasil analisis menggunakan analisis regresi menunjukkan bahwa $F_{\text {reg }}=5,32>F_{\text {tabel }}=$ 4,30 maka hipotesis diterima dan dinyatakan ada pengaruh yang signifikan antara pemanfaatan media poster dengan perilaku siswa dalam menjaga kebersihan lingkungan di kelas II Mi Nashrul Fajar Meteseh Tembalang Semarang tahun pelajaran $2017 .^{11}$

Menurut hasil penelitian Ulya \& Iskandar dengan judul Pengaruh Pendidikan Kesehatan Dengan Media Poster Terhadap Pengetahuan Manajemen Hipertensi Pada Penderita Hipertensi didapatkan hasil dari uji Paired t-test terdapat perbedaan peningkatan pengetahuan yang signifikan pada kelompok intervemsi $(\mathrm{p}=0,000)$ dibandingkan kelompok control $(\mathrm{p}=0,194)$. Hasil uji Independent t-test menunjukkan ada peningkatan pengetahuan antara kelompok intervensi dan kontrol $(\mathrm{p}=0,016)$. Pendidikan kesehatan dengan media poster efektif meningkatkan pengetahuan manajemen hipertensi pada penderita 
hipertensi. Melihat kedua hasil penelitian tersebut, penulis akhirnya tertarik menggunakan poster sebagai media dalam penelitian ini. ${ }^{12}$

Berdasarkan uraian diatas, sangat penting untuk menyusun langkahlangkah pencegahan penularan COVID-19 dan memutus rantai transmisi melalui pemberian pendidikan kesehatan sehingga peneliti tertarik untuk meneliti apakah ada pengaruh pendidikan kesehatan dengan media poster terhadap perilaku pencegahan penularan COVID-19 dengan sasaran sekaa teruna teruni yang ada di Desa/Kelurahan Gilimanuk.

\section{METODE}

Jenis penelitian ini adalah pre experimental design dengan rancangan penelitian one-group pra-post test design. Populasi penelitian ini yaitusekaa teruna teruni di Desa gilimanuk. Teknik sampling yang digunakan adalah probability sampling dengan stratified random sampling yang berjumlah 77 orang.

Data yang dikumpulkan adalah data primer yaitu perilaku pencegahan Covid-19 dengan menggunakan kuesioner dengan 35 item pernyataan menggunakan skala likert (sikap) dan guttman (pengetahuan dan tindakan). Kedua kuesioner tersebut telah dilakukan uji validitas dan reliabilitas, didapatkan semua butir pernyataan dinyatakan valid dan reliabel. Pengukuran perilaku pencegahan Covid-19 dilakukan sebelum dan setelah pendidikan kesehatan dengan media poster. Penelitian ini dianalisis dengan uji wilcoxon. Penelitian ini menggunakan $\alpha$ $=0,05$. Jika $\mathrm{p}<\alpha$ maka H0 ditolak yang berarti ada pengaruh pendidikan kesehatan dengan media poster terhadap perilaku pencegahan Covid-19 pada sekaa teruna teruni.

\section{HASIL DAN PEMBAHASAN}

Karakteristik sekaa teruna teruni di Desa Gilimanuk meliputi usia, jenis kelamin, pendidikan, dan pekerjaan hasil disajikan dalam tabel sabagai berikut : 
I Gusti Ketut Gede Ngurah, I Gusti Ayu Ngurah Viola Utami Dewi. Desember 2021. 14 (2): 83-95

Tabel 1 Distribusi Frekuensi Responden Berdasarkan Usia

\begin{tabular}{ccc}
\hline Usia (th) & Frekuensi (n) & Persentase (\%) \\
\hline $17-19$ & 26 & 33,8 \\
\hline $20-22$ & 18 & 23,4 \\
\hline $23-25$ & 33 & 42,8 \\
\hline Jumlah & 77 & 100 \\
\hline
\end{tabular}

Berdasarkan tabel 1, menunjukkan bahwa usia responden terbanyak yaitu usia 23-25 tahun sebanyak 33 orang $(42,8 \%)$.

Tabel 2 Distribusi Frekuensi Responden Berdasarkan Jenis Kelamin

\begin{tabular}{ccc}
\hline Jenis Kelamin & Frekuensi (n) & Persentase (\%) \\
\hline Laki-laki & 32 & 41,6 \\
\hline Perempuan & 45 & 58,4 \\
\hline Jumlah & 77 & 100 \\
\hline
\end{tabular}

Berdasarkan tabel 2, menunjukkan bahwa jenis kelamin responden terbanyak yaitu perempuan sebanyak 45 orang $(58,4 \%)$.

Tabel 3 Distribusi Frekuensi Responden Berdasarkan Pendidikan

\begin{tabular}{ccc}
\hline Pendidikan & Frekuensi (n) & Persentase (\%) \\
\hline SMA/SMK & 20 & 26,0 \\
\hline Perguruan Tinggi & 57 & 74,0 \\
\hline Jumlah & 77 & 100 \\
\hline
\end{tabular}

Berdasarkan tabel 3, menunjukkan bahwa pendidikan responden terbanyak yaitu perguruan tinggi sebanyak 57 orang $(74,0 \%)$.

Tabel 4 Distribusi Frekuensi Responden Berdasarkan Pendidikan

\begin{tabular}{ccc}
\hline Pekerjaan & Frekuensi (n) & Persentase (\%) \\
\hline Pelajar & 44 & 57,1 \\
\hline Karyawan swasta & 13 & 16,9 \\
\hline Wirausaha & 20 & 26,0 \\
\hline Jumlah & 77 & 100 \\
\hline
\end{tabular}

Berdasarkan tabel 4, menunjukkan bahwa pekerjaan responden terbanyak yaitu pelajar sebanyak 44 orang $(57,1 \%)$.

Hasil pengamatan terhadap klien hipertensi berdasarkan tingkat stres, perilaku pencegahan stroke dan analisis bivariat disajikan dalam tabel sebagai berikut : 
I Gusti Ketut Gede Ngurah, I Gusti Ayu Ngurah Viola Utami Dewi. Desember 2021. 14 (2): 83-95

Tabel 5 Distribusi Frekuensi Perilaku Pencegahan Covid-19 Sebelum Perlakuan

\begin{tabular}{lcccccc}
\hline \multirow{3}{*}{ Kategori } & \multicolumn{6}{c}{ Sebelum Perlakuan } \\
\cline { 2 - 8 } & Pengetahuan & \multicolumn{2}{c}{ Sikap } & \multicolumn{2}{c}{ Tindakan } \\
\cline { 2 - 7 } & $\mathbf{f}$ & \% & f & \% & f & \% \\
\hline Baik & 25 & 32,5 & 48 & 62,3 & 27 & 35,0 \\
\hline Cukup & 29 & 37,7 & 22 & 28,6 & 25 & 32,5 \\
\hline Kurang & 23 & 29,8 & 7 & 9,1 & 25 & 32,5 \\
\hline Jumlah & 77 & 100 & 77 & 100 & 77 & 100 \\
\hline
\end{tabular}

Berdasarkan tabel 5, menunjukkan bahwa perilaku pencegahan Covid-19 pada responden sebelum diberikan perlakuan yaitu sebagian besar memiliki pengetahuan yang cukup yaitu sebanyak 29 orang (37,7\%), sebagian besar sikap responden baik yaitu 48 orang $(62,3 \%)$, dan sebagian besar tindakan responden baik yaitu 27 orang $(35,0 \%)$.

Tabel 6 Distribusi Frekuensi Perilaku Pencegahan Covid-19 Setelah Perlakuan

\begin{tabular}{lcccccc}
\hline \multirow{3}{*}{ Kategori } & \multicolumn{6}{c}{ Setelah Perlakuam } \\
\cline { 2 - 8 } & \multicolumn{1}{c}{ Pengetahuan } & \multicolumn{2}{c}{ Sikap } & \multicolumn{2}{c}{ Tindakan } \\
\cline { 2 - 7 } & $\mathbf{f}$ & $\mathbf{\%}$ & $\mathbf{f}$ & $\mathbf{\%}$ & $\mathbf{f}$ & $\mathbf{\%}$ \\
\hline Baik & 77 & 100 & 77 & 100 & 77 & 100 \\
\hline Cukup & 0 & 0 & 0 & 0 & 0 & 0 \\
\hline Kurang & 0 & 0 & 0 & 0 & 0 & 0 \\
\hline Jumlah & 77 & 100 & 77 & 100 & 77 & 100 \\
\hline
\end{tabular}

Berdasarkan tabel 6, menunjukkan bahwa perilaku pencegahan Covid-19 pada responden setelah diberikan perlakuan semuanya dari pengetahuan, sikap dan tindakan memiliki kategori baik yaitu 77 orang (100\%). 
I Gusti Ketut Gede Ngurah, I Gusti Ayu Ngurah Viola Utami Dewi. Desember 2021. 14 (2): 83-95

Tabel 7 Analisis Bivariat Pengaruh Pendidikan Kesehatan Dengan Media Poster Terhadap Perilaku Pencegahan Covid-19 Pada Sekaa Teruna Teruni

\begin{tabular}{|c|c|c|c|c|c|c|c|c|c|}
\hline \multirow{3}{*}{$\begin{array}{c}\text { Perilaku } \\
\text { Sebelum } \\
\text { Perlakuan }\end{array}$} & \multicolumn{6}{|c|}{ Perilaku Setelah Perlakuan } & & & \multirow{3}{*}{$\underset{\text { value }}{\mathbf{p}}$} \\
\hline & \multicolumn{2}{|c|}{ Baik } & \multicolumn{2}{|c|}{ Cukup } & \multicolumn{2}{|c|}{ Kurang } & \multicolumn{2}{|c|}{ Jumlah } & \\
\hline & $\mathbf{f}$ & $\%$ & $\mathbf{f}$ & $\%$ & $\mathbf{f}$ & $\%$ & $\mathbf{f}$ & $\%$ & \\
\hline \multicolumn{9}{|l|}{ Pengetahuan } & \multirow{15}{*}{0,000} \\
\hline Baik & 25 & 32,5 & 0 & 0 & 0 & 0 & 25 & 32,5 & \\
\hline Cukup & 29 & 37,7 & 0 & 0 & 0 & 0 & 29 & 37,7 & \\
\hline Kurang & 24 & 29,8 & 0 & 0 & 0 & 0 & 24 & 29,8 & \\
\hline Jumlah & 77 & 100 & 0 & 0 & 0 & 0 & 77 & 100 & \\
\hline \multicolumn{9}{|l|}{ Sikap } & \\
\hline Baik & 48 & 62,3 & 0 & 0 & 0 & 0 & 48 & 62,3 & \\
\hline Cukup & 22 & 28,6 & 0 & 0 & 0 & 0 & 22 & 28,6 & \\
\hline Kurang & 7 & 9,1 & 0 & 0 & 0 & 0 & 7 & 9,1 & \\
\hline Jumlah & 77 & 100 & 0 & 0 & 0 & 0 & 77 & 100 & \\
\hline \multicolumn{9}{|l|}{ Tindakan } & \\
\hline Baik & 27 & 35,0 & 0 & 0 & 0 & 0 & 27 & 35,0 & \\
\hline Cukup & 25 & 32,5 & 0 & 0 & 0 & 0 & 25 & 32,5 & \\
\hline Kurang & 23 & 32,5 & 0 & 0 & 0 & 0 & 23 & 32,5 & \\
\hline Jumlah & 77 & 100 & 0 & 0 & 0 & 0 & 77 & 100 & \\
\hline
\end{tabular}

Berdasarkan tabel 7, didapatakan bahwa responden yang memiliki perilaku pencegahan Covid-19 yang baik, cukup dan kurang pada indikator pengetahuan sebelum diberikan perlakuan semuanya menjadi memiliki perilaku pencegahan yang baik setelah diberikan perlakuan dengan persentase masing-masing yaitu $32,5 \%, 37,5 \%$ dan 29,8\%. Responden yang memiliki perilaku pencegahan Covid19 yang baik, cukup dan kurang pada indikator sikap sebelum diberikan perlakuan semuanya menjadi memiliki perilaku pencegahan yang baik setelah diberikan perlakuan dengan persentase masing-masing yaitu $62,3 \%, 28,6 \%$ dan $9,1 \%$. Sedangkan responden yang memiliki perilaku pencegahan Covid-19 yang baik, cukup dan kurang pada indikator tindakan sebelum diberikan perlakuan semuanya menjadi memiliki perilaku pencegahan yang baik setelah diberikan perlakuan dengan persentase masing-masing yaitu $35,0 \%, 32,5 \%$ dan $32,5 \%$.

Hasil analisis bivariat didapatkan bahwa nilai $\mathrm{p}=0,000$, karena nilai $\mathrm{p}<\alpha$ $(0,05)$, maka $\mathrm{H}_{0}$ ditolak. Hal ini berarti bahwa ada pengaruh pendidikan kesehatan dengan media poster terhadap perilaku pencegahan Covid-19 pada sekaa terunateruni di Desa/Kelurahan Gilimanuk. 
I Gusti Ketut Gede Ngurah, I Gusti Ayu Ngurah Viola Utami Dewi. Desember 2021. 14 (2): 83-95

Berdasarkan hasil penelitian yang dilakukan terhadap 77 responden menunjukkan bahwa, adanya peningkatan perilaku dari sebelum diberikan pendidikan kesehatan hingga setelah diberikan pendidikan kesehatan yaitu pengetahuan responden dalam kategori cukup sebanyak 23 orang (29.9\%), kategori kurang sebanyak 29 orang (37.7\%), sikap responden dalam kategori cukup sebanyak 22 orang (28.6\%), kategori kurang sebanyak 7 0rang (9.1\%), serta tindakan responden dalam kategori cukup dan kurang masing-masing sebanyak 25 orang (32.5\%). Hal ini membuktikan bahwa sikap dan tindakan sebagian besar responden sudah baik, sedangkan dalam segi pengetahuannya masih kurang karena sebagian besar pengetahuan responden berada dalam kategori cukup. Dari hasil tersebut, masih minimnya pengetahuan yang dimiliki oleh sekaa teruna-teruni di Desa/Kelurahan Gilimanuk mengenai pencegahan penularan coronavirus disease (COVID-19) perlu ditingkatkan, kemudian setelah diberikan pendidikan kesehatan semua responden masuk dalam kategori baik, kategori cukup dan kurang menjadi 0\%. Sehingga hasil penelitian ini menunjukkan adanya pengaruh yang signifikan dalam perilaku pencegahan coronavirus disease (COVID-19) dengan nilai p yaitu 0,000 .

Hasil penelitian ini sesuai dengan hasil penelitian yang telah dilakukan oleh Ulum, yang berjudul "Pengaruh Pemanfaatan Media Poster Terhadap Perilaku Siswa Dalam Menjaga Kebersihan Lingkungan Di Kelas II Mi Nashrul Fajar Meteseh Tembalang Semarang Tahun Pelajaran 2016/2017" hasil penelitian menunjukkan bahwa pemanfaatan media poster di MI Nashrul Fajar dalam kategori "sedang" dengan nilai rata-rata sebesar 82,13. Sedangkan, perilaku siswa dalam menjaga kebersihan lingkungan di kelas II MI Nashrul Fajar dalam kategori "sedang" dengan nilai rata-rata sebesar 76,29. Hasil analisis menggunakan analisis regresi menunjukkan bahwa Freg $=5,32>$ Ftabel $=4,30$ maka hipotesis diterima dan dinyatakan ada pengaruh yang signifikan antara pemanfaatan media poster dengan perilaku siswa dalam menjaga kebersihan lingkungan di kelas II MI Nashrul Fajar Meteseh Tembalang Semarang tahun pelajaran 2016/2017. Simpulan dari hasil penelitian ini adalah pemanfaatan media poster di MI Nashrul Fajar dalam kategori "sedang". Perilaku siswa dalam menjaga kebersihan 
I Gusti Ketut Gede Ngurah, I Gusti Ayu Ngurah Viola Utami Dewi. Desember 2021. 14 (2): 83-95

lingkungan di kelas II MI Nashrul Fajar dalam kategori “sedang”. Serta, ada pengaruh yang signifikan antara pemanfaatan media poster terhadap perilaku siswa dalam menjaga kebersihan lingkungan di kelas II MI Nashrul Fajar Meteseh Tembalang Semarang tahun pelajaran 2016/2017. ${ }^{11}$

Analisis dari peneliti adalah dari hasil penelitian ini dan penelitian terkait perilaku pencegahan coronavirus disease (COVID-19) dapat ditingkatkan apabila masyarakat mendapatkan informasi yang baik dan benar baik dari segi isi informasi maupun cara penyampaian informasi tersebut sehingga seseorang yang akan diberikan infromasi tersebut dapat memahami dengan baik. Semakin menarik cara penyampaian informasi semakin mudah audience menyerap informasi yang diberikan, banyak terdapat media pembelajaran dalam peneyebaran infromasi salah satunya yang sudah dibuktikan terdapat pengaruh adalah menggunakan media poster.

\section{SIMPULAN}

Berdasarkan hasil penelitian terhadap 77 responden didapatkan bahwa perilaku pencegahan coronavirus disease (COVID-19) pada sekaa teruna teruni sebelum diberikan pendidikan kesehatan sebagian besar pengetahuan dalam kategori cukup (37.7\%), sikap dalam kategori baik (62.3\%), dan tindakan dalam kategori baik (35.1\%). Perilaku pencegahan coronavirus disease (COVID-19) pada sekaa teruna- teruni setelah diberikan pendidikan kesehatan, pengetahuan, sikap dan tindakan semua dalam kategori baik. Penelitian ini menemukan bahwa ada pengaruh yang signifikan pendidikan kesehatan dengan media poster terhadap perilaku pencegahan coronavirus disease (COVID-19) pada sekaa teruna-teruni di Desa/Kelurahan Gilimanuk dengan nilai $\mathrm{p}=0,000$.

\section{UCAPAN TERIMAKASIH}

Peneliti mengucapkan terima kasih kepada Kepala Desa/Kelurahan Gilimanuk yang telah berkenan memberikan ijin untuk mengambil data penelitian di wilayah kerja puskesmas dan fasilitas yang telah diberikan selama peneliti melakukan penelitian. 
I Gusti Ketut Gede Ngurah, I Gusti Ayu Ngurah Viola Utami Dewi. Desember 2021. 14 (2): 83-95

\section{ETHICAL CLEARENCE}

Etika penelitian diperoleh dari Komisi Etik Penelitian Politeknik Kesehatan Denpasar dengan Nomor Kaji Etik LB.02.03/EA/KEPK/0363/2021.

\section{DAFTAR RUJUKAN}

1. WHO. Coronavirus Disease (COVID-19) [Internet]. 2020 [cited 2021 Jan 24]. Available from: https://doi.org/10.1891/9780826153425.0016b

2. Handayani D. Penyakit Virus Corona 2019. J Respiralogi Indones. 2020;40(2):119.

3. Yanti E, Fridalni N, Harmawati. Mencegah Penularan Virus Corona. J Abdimas Saintika. 2020;2.

4. KPCPEN. Beranda Satgas Penanganan COVID-19: Satgas Covid -19 [Internet]. 2020 [cited 2021 Jan 9]. Available from: https://covid19.go.id

5. Dinas Komunikasi dan Informatika Kota Denpasar. Covid-19: Denpasar Safe City [Internet]. 2020 [cited 2021 Jan 10]. Available from: https://safecity.denpasarkota.go.id/id/covid19\%250

6. Pemkab Jembrana. Jembrana Tanggap COVID-19 [Internet]. 2020 [cited 2021 Jan 10]. Available from: http://covid19.jembrana.go.id/

7. Notoadmodjo S. Promosi Kesehatan dan Ilmu Perilaku. Jakarta: Rineka Cipta; 2014.

8. Güner R, Hasanoğlu İ, Aktaş F. Covid-19: Prevention and control measures in community. Turkish Journal of Medical Sciences. Turkish J Med Sci. 2020;50(SI-1):571-7.

9. Ali HZ. Dasar-Dasar Pendidikan Kesehatan Masyarakat dan Promosi Kesehatan. Jakarta: Trans Info Media; 2010.

10. Wongsawat S. Integrating Posters And Actual-Sized Fruit Models In Health Education On Fruit Diets For Elderly Patients. Int J Arts Sci. 2015;08(03):717-23.

11. Ulum AF. Pengaruh Pemanfaatan Media Poster Terhadap Perilaku Siswa dalam Menjaga Kebersihan Lingkungan di Kelas II MI Nashrul Fajar Meteseh Tembalang Semarang Tahun Pelajaran 2016/2017. 2017.

12. Ulya Z, Iskandar A. Pengaruh Pendidikan Kesehatan Dengan Media Poster Terhadap Pengetahuan Manajemen Hipertensi Pada Penderita Hipertensi. J Keperawatan Soedirman. 2017;12(1):38.

13. Notoatmodjo S. Ilmi Perilaku Kesehatan. Jakarta: Rineka Cipta; 2014. 